\title{
The Authority Of Borderland Management In Indonesia
}

\author{
Nandang Alamsah Deliarnoor \\ Department of Government Science Padjadjaran University, \\ Bandung, Indonesia \\ Nuraini Els Jasmine Abidin \\ Department of Law Padjadjaran University, \\ Bandung, Indonesia
}

\begin{abstract}
Indonesia as one of the archipelago countries has the islands as the front or border area. The management of the border and small islands with the outer involvement of many stakeholders both at the center and in the region, given the fact that this area is still lagging far from other areas. In addition, it is necessary to harmonize between state governments in the management of each country's border and its regulation. One of the important aspects related to the borderland is the issue of authority. The management of border areas and outer islands has not been as expected because there is no synergy between the government and local government and other stakeholders. Using normative juridical approach in terms to explain in detail and conduct in-depth analysis of government authority in the management of border areas in Indonesia. The borderland has border-related issues from various aspects; in addition there is disharmonization of the borderland which then there is harmonization of legislation in the framework of borderland management has also formulated some basic principles proposed to be used as a reference for the preparation of local regulations. One further effort in creating harmonization and synchronization of legislation in governance in the archipelago, namely by empowering maintained archives. In connection with the results of research on borderland management in Indonesia, a separate ministry of borders on borderland management in Indonesia should be established, and adopt other countries that manage borders, especially archipelagic forms.
\end{abstract}

Keywords: authority, governance, borderland, borderland management

\section{INTRODUCTION}

Geographically, Indonesia is one of the largest archipelagic countries in the world with thousands of islands spreading in marine areas, with 17,508 large and small islands and the second longest coastline of $81,900 \mathrm{~km}$. As an archipelagic country, Indonesia lies between two continents, the Asian Continent and the Australian Continent, and two oceans, the Pacific Ocean and Indian Ocean. Land territory, Indonesia is bordered directly with 3 (three) countries, namely Malaysia, Papua New Guinea, and Timor Leste with the overall land border is 2914.1 $\mathrm{km}$. While the sea territory of Indonesia is bordered by 10 countries, Malaysia, Singapore, Philippines, India, Vietnam, Thailand, the Republic of Palau, Australia, Timor Leste and Papua New Guinea. Islands in Indonesia have coastal and coastal boundaries. Indonesia has its foremost and lagging islands, each of which has 111 islands. In addition, there are 10 locations of borderland and distribution of 26 cities of national strategic activity centers on the border as regulated in Government Regulation No. 26 of 2008 on National Spatial Plan. ${ }^{1}$

${ }^{1}$ Nandang Alamsah Deliarnoor, "Management of Boderland in Context of Comtemporary Government", presented at National Seminar, (presented at Islam University Riau, Pekanbaru, 24 November 2017) 
Characteristics of each archipelago vary, including the government administration. Administration of the government is regulated in Law No. 23 of 2014 on Local government covering the affairs of compulsory government and concurrent government affairs. The administration of the State includes the implementation of the functions of government. The functions of government in question include the function of protection, defense function, law enforcement function, development function, empowerment function, service function and function of inter-governmental relationship. In the dimension of the implementation of intergovernmental relations function, implementation of management policy of small outer islands at the border ideally can support the establishment of harmonious social-economic and socialcultural citizens relations in each country border and also support the harmony of relations between state governments in managing border of each State.

The outer country border and the outer islands have become an interesting and strategic national issue that is getting the spotlight from various societies. The complexity of the problems such as being left behind, isolated, poverty, vulnerable to infiltration, low quality of human resources, limited infrastructure, natural resources have not been optimally managed and vulnerable to food ${ }^{2}$ and are vulnerable to conflicts and violations of law and territorial and other ramps are common problems requiring serious attention and handling. Events that occur in this region have always had a huge political impact and gave rise to national sentiments. ${ }^{3}$ The lack of access to borderland is due to the lack of central and local government budgets for the development of border districts with remote and outlying locations. The limitations of access to border infrastructure mainly include transportation, energy, communications and information. Development of borderlands is done by changing the direction of development policy initially oriented "inward looking" to "outward looking". One of the policies of borderland development in the RPJMN 2015-2019 is to accelerate the development of borderlands in various fields as the vanguard of the country, as well as the gateway of economic and trade activities with neighboring countries in an integrated and environmentally friendly way to improve the welfare of the community and strengthen national security defense. ${ }^{4}$

One of the important aspects related to the borderland is the issue of authority. The issue of administrative area authority and the complexity of development involving many parties and sectors, affect the management of borderlands. There is still an interesting tug and overlapping authority between the Central Government and Local Government in the implementation of development plans and management of borderlands regulated in legislation. The borderland covers various aspects. Viewed from the legal aspect, there are a legal basis related to the borderland, among others, as follows:

1. Law No. 26 of 2007 on Spatial Planning;

2. Law No. 27 of 2007 on Management of Coastal Area and Small Islands;

3. Law No. 43 of 2008 on State Territories;

4. Law No. 1 of 2014 on Amendment of Law No. 27 of 2007 on Management of Coastal Area and Small Islands;

5. Law No. 23 of 2014 on Local government;

6. Government Regulation No. 26 of 2008 on National Spatial Plan;

\footnotetext{
${ }^{2}$ Akhmad Musyafak, Mapping Agroecosystem and Socio-Economic for Border of Bengkayang-Serawak Agricultural Development West Kalimantan, (Yogyakarta: Deepublish), 2015, p. 2

3 Indepth the study of borderland issues can be accessed on the website http://kawasan.bappenas.go.id, downloaded on 12 January 2017 p. 4

${ }^{4}$ Riyadi, et.al., People's Welfare Indicator 2015 Welfare Indicators 2015, Jakarta: Central Bureau of Statistics, 2015, 2015,
} 
7. Government Regulation No. 62 of 2010 concerning Utilization of the Smaller Outermost Islands;

8. Government Regulation No. 11 of 2017 concerning Spatial Plan of State Borderland;

9. Presidential Regulation No. 11 of 2017 on Spatial Planning of State Borderland in North Sulawesi Province, Gorontalo Province, Central Sulawesi Province, East Kalimantan Province and North Kalimantan Province; and

10. Presidential Regulation No. 44 of 2017 on the Amendment of Presidential Regulation no. 12 of 2010 on the National Border Management Agency.

11. Regulation of the Head of Archive No. 41 of 2015 on Management of Maintained Archive

Borderland, as regulated in Article 1 point 6 of Law No. 43 of 2008 on State Territory, is part of the territory of the country located on the inside side of the border of Indonesia with other countries, in the case of borderlands on the land, the borderland is in the subdistrict. Indonesia as described in Article 6 paragraph (1) of Law no. 43 of 2008 is directly adjacent to Singapore, Malaysia, Papua New Guinea, Timor Leste. Furthermore, related to the authority of borderland management is regulated in Law no. 23 of 2014 on Local government. Article 361 and Article 362 of Law no. 23 of 2014 set around the borderland of the State, the outer sub-districts that directly adjacent to other countries. In addition, there is a provision concerning institutions engaged in the management of borderlands, namely the National Border Management Agency or as in Badan Nasional Pengelolaan Perbatasan (BNPP) in Presidential Regulation no. 44 of 2017 on the Amendment of Presidential Regulation no. 12 of 2010 on Badan Nasional Pengelolaan Perbatasan (BNPP).

The management of the outer border and small islands involving many stakeholders both at the center and in the region (local), given the fact that the area is still lagging far from other regions and always be the focus of various social vulnerabilities. The powerlessness of the central government in addressing the complexity of the issues in this area has led to the need for an alternative search involving the role of all interested parties. The failure of the system and the attention that implements the management of one dominant actor, namely the central government, ${ }^{5}$ still leaves this region remains neglected and backward from various fields of development. Development carried out so far is still partial and very sectoral. ${ }^{6}$

However, the coordination, integration, synchronization and synergy of border management programs at both central and regional levels have not been effectively implemented, as well as ineffective institutional management efforts among countries to support cross border activities and the integration of borderland management with neighboring countries and limited resources, supporters, and human resources of border management institutions. ${ }^{7}$ The condition of the people around the borderland of the country such as separated from the attention of local governments and the handling of the problem of boundary regions into central government domains only. This fact shows many policies that are not mutually supportive and/or less synchronized with each other. Management of borderland and outer islands involving many institutions (Ministries), both at the central level as well as between central and local governments run in their respective interests.

\footnotetext{
5 Sutaryo, et.al., Building the Sovereignty of Nations Based on Pancasila Values: Community Empowerment in the Outermost, Left, and Underdeveloped Area (3T). Yogyakarta: Central Pancasila UGM Team, 2015, p. 567

${ }^{6}$ Ishak, Awang Faroek, Development of border areas of Kalimantan in order to maintain and maintain national integrity, Jakarta: Indomedia, 2003, p. 16

${ }^{7}$ Attachment to Regulation of the Head of BNPP No. 2 of 2015 Date: 13 April 2015 Tentan Strategic Plan National Border Management Agency 2015-2019
} 
With regard to the authority of the central government in the management of the border so far only exists on the border gate, which includes aspects of customs, immigration, quarantine, security and defense. Meanwhile, local governments have the potential to develop and enhance the borderland other than those entrances. Nevertheless, the limited authority so that local governments can not play their full role in the management of the region. Another factor is the inadequate capacity in borderland management, given that the handling is crossadministrative and cross-sectoral, thus still requiring coordination from higher hierarchical institutions. ${ }^{8}$

Lack of coordination between governments both central and local areas raises the issue of the pros and cons in the border community over the development. The spirit of acceleration of development carried by various institutions precisely cause the failure of the program due to each party only impose its interests. One fact related to this is like the construction of the ring road of Miangas Island, Talaud Islands District, North Sulawesi, along 5.2 kilometers threatened to fail. Pros and cons on land issues where part of the land used as roads is the area of coconut plantations and tubers that are the mainstay of citizens to overcome hunger. The construction of this road by the North Sulawesi National Road Implementing Agency and Gorontalo $^{9}$ has the purpose of building a ring road in the borderland to facilitate access of people traveling around the island. However, in terms of community needs and also local government programs have differences on this.

The issue of coordination of this miangas development is demonstrated by the facts about the Lack of Trade Facilities, Lack of Border Security Facilities, the Unavailability of Commodity Processing Facility, Lack of Education and Training Facilities, where there is no clarity of the parties responsible for this. In relation to this matter, both central and regional agencies have the authority to provide the construction of such facilities.

The Indonesian border to date has a complex dimension, there are a number of crucial factors involved in it, both in terms of state jurisdiction and sovereignty, political, social, economic, and state defense. Broadly speaking, there are three main issues in the management of borderland between countries, namely the determination of boundaries both on land and at sea; borderland security; and the development of borderland. Many borderland are subject to economic backwardness due to the absence of government and private programs and projects. The length of the borderline both on land and oceans is very difficult to be monitored regularly by security forces. As a result, violations of borderland, smuggling, and other illegal cross border activities often occur. If the borderland is not immediately managed properly and effectively, certainly the sovereignty of the state will soon be at stake. In addition, the inhabitants of the border region have more emotional closeness and socio-economic interaction with the people of neighboring countries. ${ }^{10}$

Based on the explanation above, it shows that the management of borderland and outer islands has not been as expected because there is no synergy between the governments and other stakeholders. The Local government as the government's organizer and the development in the autonomous region, has not taken a more intensive role in the management of borderland.

\footnotetext{
8Zulkifli, International Cooperation as a Solution for the Management of the State Border Area (Case Study of Indonesia), Jakarta, 2012

${ }^{9}$ Kompas, Article: https://www.pressreader.com/indonesia/kompas/20170911/281938838074234 , downloaded at Kompas.com, 11 Sep 2017

10 Partnership Partnership, Policy Paper No. 2/2011: Indonesia Border Area Management Policy, May 2011, p. 3-4, can be accessed on the website www.kemitraan.or.id
} 
There needs to be a pattern of coordination in the management of borderland and outer islands. It is therefore necessary to analyze the authority of regional management in Indonesia.

\section{RESEARCH METHODS}

This study uses a normative juridical approach is an approach made based on the main legal material by reviewing theories, concepts, legal principles and legislation related to this research. In addition, this research approach uses qualitative research methods. The research tries to explain in detail and conduct an in-depth analysis of government authority in the management of borderland in Indonesia. The data needed in this study consists of two types namely primary data and secondary data. Primary data is obtained directly from informants/resource persons who understand the research problem related to borderland. Secondary data is data that has been processed in the form of data or facts related to the borderland.

\section{Borderland problems}

\section{RESULTS AND DISCUSSION}

In practice, there are problems in the borderland, as described by the Regional Development Planning Board of Riau Islands Province among others as follows: ${ }^{11}$

1. The borderland is very wide;

2. There is still a lack of management of potential and natural resources by both state and private sector;

3. The handling of the border has not been maximized and is still partial or sectoral;

4. Low level of education and welfare compared to neighboring communities such as Malaysia and Singapore;

5. Lack of security and defense facilities and infrastructures, this has led to weak supervision over various state border violations;

6. Uncomplicated programs and activities of borderland development.

While, the problems that exist in borderlands generally include: 12

1. The absence of certainty of the boundary line, both the maritime boundary and the land boundary line, and the administration and maintenance. As a result, the borderland development planning becomes constrained. The existence of this state boundary issue has many negative impacts and various incidents on the border and violations of the territory of sovereignty.

2. Local community conditions in borderlands are generally still poor, underdeveloped, underdeveloped, low levels of education and health, and isolated communities.

3. Weak law enforcement, causing widespread violations of law in borderland. Implementation of border and customs, immigration and quarantine (customs, immigration and quarantine) border posts is not optimal and constrained by many things, resulting in illegal cross-border activities.

4. Not yet synchronous management of borderland, both regarding institutions, programs, and clarity of authority.

5. The existence of smuggling activities of goods and Indonesian Workers (TKI)

6. Vulnerable issues related to the nationalism of the population due to the lack of information entering from Indonesia, and the people in the border region more familiar with neighboring countries than the country itself.

\footnotetext{
11 Regional Development Planning Board of Province of Riau Islands, Exposure Presentation: Case Study of Border Area Management in Province of Riau Islands, p. 14

12 Op.cit
} 
Based on problems above, Problem No. 4 best suited to this study, due to research in terms of authority. Furthermore, when viewed from the physical and infrastructure aspects, the characteristics of borderland have the following problems: ${ }^{13}$

1. Land boundary in the borderland is very concerning, because many of the boundary boundaries are missing and some of them are in poor condition. To the maritime boundary, Indonesia as a party to the United Nations Convention on the Law of the Sea 1982 (UNCLOS), has several maritime boundary regimes to be completed with ten neighboring states, either border determinations, or related to border affirmation that has not been completed.

2. In general, land borderland are located in isolated and inland areas with difficult to reach natural conditions.

3. Forests in borderland are generally natural forests and most are categorized as conservation areas or protected forest areas.

4. Infrastructure in the borderland is relatively limited and requires more serious handling.

Furthermore, there are some differences in the management of outer islands with other countries including archipelago countries that have borderlands such as Indonesia. Here is the Governance of the Outlying Islands With Other Countries:

Table 1. The Governance of the Outlying Islands With Other Countries

\begin{tabular}{|c|c|c|c|}
\hline Countries & $\begin{array}{c}\text { Policy } \\
\text { Institution }\end{array}$ & Regulations & Difference with Indonesia \\
\hline Philippines & $\begin{array}{l}\text { Cabinet } \\
\text { Committee on } \\
\text { Maritime and } \\
\text { Ocean Affairs }\end{array}$ & UNCLOS 1982 & $\begin{array}{l}\text { Not establishing special institutions such } \\
\text { as Indonesia, causing many oceans to be } \\
\text { unmanned, and lacking ZEE }\end{array}$ \\
\hline $\begin{array}{l}\text { United } \\
\text { Kingdom }\end{array}$ & $\begin{array}{c}\text { Ministry of } \\
\text { Foreign Affairs }\end{array}$ & ZEE/UNCLOS 1982 & $\begin{array}{l}\text { Building infrastructure in the outer } \\
\text { islands. Building military bases and } \\
\text { placing communities to inhabit and } \\
\text { manage small outer islands, while } \\
\text { Indonesia still has many outer islands } \\
\text { uninhabited and untouched }\end{array}$ \\
\hline China & $\begin{array}{l}\text { Department of } \\
\text { defense }\end{array}$ & $\begin{array}{l}\text { Inserting Spratly } \\
\text { and Paracel into its } \\
\text { maritime area of } \\
200 \text { miles from the } \\
\text { sea, causing the } \\
\text { seizure of Spratly } \\
\text { Island }\end{array}$ & $\begin{array}{l}\text { Not obeying UNCLOS } 1982 \text {, then building } \\
\text { islands in the Spratly region and sending } \\
\text { Chinese residents to inhabit there as well } \\
\text { as build military bases }\end{array}$ \\
\hline Malaysia & $\begin{array}{c}\text { Ministry of } \\
\text { Foreign Affairs }\end{array}$ & UNCLOS 1982 & $\begin{array}{l}\text { Build infrastructure on the outer islands } \\
\text { and place residents and military bases }\end{array}$ \\
\hline
\end{tabular}

Source: Hasim As'ari, 2017

In the management of the outermost small islands, the governance of countries as mentioned above is a finding that can be used as a reference for Indonesia in improving the management

${ }^{13}$ Hasim As'ari, Dissertation: Implementation of Policy Management of Small Islands Outlying in Province of Riau Islands, Bandung: Unpad, 2017, p. 280 
of the small outer islands in Indonesia, especially by building infrastructure, locating residents and building military bases on the island small islands to facilitate control of state sovereignty.

In addition, the main thing to consider in designing a state border management institution is the multi-stakeholder involvement of management, within the framework of a collaborative border governance system, which is a border management approach that invites multiple stakeholders to achieve goals and to accomplish problems together. The governance of state borders should be formulated and comprehensively, by:14

1. to define precisely and clearly the institutional environment affecting the performance of border state management;

2. formulating the networking and policy network required to support the performance of state border management;

3. to formulate and establish the standard of institutional capability required for the management of state borders; and

4. designing the appropriate state-of-the-art border management agency.

The affairs in the borderland are generally still handled by the central government and its staff. But in addition to its nature is still partial and less coordinated, the performance achieved is also not encouraging. Every agency with an interest in border development seeks to fight for its programs for the sake of its institutions, and it is very difficult to be released or shared with other institutions. Ministries/Non-ministerial government agencies and have no clear links in a steady coordination, so the results do not show significant progress on the border. The handling of the border so far has not been able to be done optimally and unintegrated, and often there is interest between parties, horizontally, sectorally and vertically. The not yet optimal mechanism and implementation of coordination, integration, synchronization and synergy of border management programs both at the central and regional levels. The ineffectiveness of institutional management efforts between countries in support of crossborder activities and integration of borderland management with neighboring countries and limited resources, supporting infrastructure, and human resources of border management institutions. ${ }^{15}$

The condition of the people around the borderland of the country as out of the local government's attention and the handling of the boundaries of state boundaries becomes the domain of the central government only. Similarly, West Kalimantan Governor, Cornelis, declared May 19, 2017 at the West Kalimantan Governor's Office, as quoted by Imam Edy Mulyono, asking the government to issue clear regulation on borderland management. The regulation is to avoid overlapping authority, as well as to state that who handles, should be clear. The handling is clear. The responsibility is clear, so as not to overlap, this is because lest anyone feel the most powerful in the border. ${ }^{16}$

\footnotetext{
14 Robert Simbolon, Dissertation Proposal: State Border Governance In Indonesia: Studies of Institutional Border Management Country, Bandung: Unpad, 2017, p. 84

15 Imam Edy Mulyono, Dissertation Proposal: Analysis of Coordination Patterns of Government Institutions in Border Management and Small Island Outlying (Study on Miangas Island of Talaud Regency of North Sulawesi Province), Bandung: Unpad, 2017, p. 6-7

16 Ibid
} 


\section{Review of the Authority of the Provincial Government in the Management of the Border Area \\ Concept of Authority}

In a modern state of law, in which the state interferes in all fields of public life, the government is also given the task of "assigning tasks" or "taakstelling" or "political duty". While this task is not its primary duty, it is in accordance with the principle of "rule state" to perform this task that should be incorporated into laws and regulations. Donner, as quoted by Philipus M. Hadjon, argues that the policy-making function or policy making includes the task-deciding power (taakstelling). Thus, the government is also given the task of formulating laws and regulations or its legal terms "legislative duties" by "delegation". Submission or transfer of power, the authority to make laws to governmental bodies is called "Delegation of Legislation" (Delegatie van wetgeving). ${ }^{17}$

Philipus M. Hadjon argues that every act of government should rest on legitimate authority. The authority is obtained by attribution, delegation, and mandate. Authority has an important position in the study of governance law. The importance of this position of authority can be seen in the concept proposed by F.A.M. Stroink and J.G. Steenbeek called it a core concept in constitutional law and state administrative law. ${ }^{18}$

Theoretically, the authority derived from the legislation is obtained through three ways of attribution, delegation, and mandate. This is seen from the opinion of experts, J.B.J.M. ten Berger, as quoted by Ridwan H.R., argued that the way an authority is administered and administered by government organs, there are three sources of authority, namely attribution, delegation, and mandate. H.D. Van Wijk / Willem Konijnenbelt also argues the same as J.B.J.M. ten Berger that there are three sources of authority. ${ }^{19}$

In addition, in a modern legal state, by taking the Donner and Hans Kelsen's teachings applicable to government practice, qualitatively the government's actions can be divided into: 20

a. The act of making the rules.

b. The act of implementing the rules.

To enforce the rules, the government undertakes concrete actions, distinguished acts into: ${ }^{21}$

a. Ordinary deeds (Feitelijke handelingen)

b. Legal Actions (Rechts handelingen)

In addition, R.J.H.M. Huisman, as quoted by Ridwan H.R, suggests that legal actions are actions that are based on their nature to give rise to certain legal consequences. ${ }^{22}$ Furthermore, there are two forms of government action based on the law, the act of government based on public law (publiekrechttelijke handeling) and the act of government based on private law (privatrechttelijke handeling). The act of public law (publiekrechtshandeling) means that the legal act undertaken by the government is based on public law in its position as the holder of

\footnotetext{
${ }^{17}$ Nandang Alamsah Deliarnoor, Governmental Law, Bandung: UNPAD Press, 2017, p. 133

${ }^{18}$ Ridwan H.R., State Administrative Law, Jakarta: Raja Grafindo Persada, 2013, p. 99

19 Nandang Alamsah Deliarnoor, et al., Theory \& Practice of Authority, Yogyakarta: Pandiva Media, 2017, p. 18

${ }^{20}$ Djenal Hosen Koesoemahatmadja, Principles of State Administrative Law, Bandung: Alumni, 1983, p. 40

${ }^{21}$ E. Utrecht, Introduction to Indonesian State Administration Law. Cet. IV, Jakarta: Ikhtiar, 1960, p. 80

${ }^{22}$ Ridwan H.R., Op.cit, p. 109
} 
government office conducted under the authority of government which is of a public legal nature which can only be born from the authority of a public legal nature as well. ${ }^{23}$

The institution according to Victor Nee, as cited by Robert Simbolon, is a system of interrelated informal and formal elements-custom, shared beliefs, conventions, norms, and rules-governing social relationships within which actors pursue and fix the limits of legitimate intersets. Institutions are social structures that provide a channel for collective action by facilitating and organizing the interests of actors and encouraging ongoing relationships between principals and agents. ${ }^{24}$

Indonesia's future border management institution must have the ability to manage the country's borders with emphasis on management based on the perspective of interstate cooperation, assuming that the approach of interstate cooperation is necessary because state borders have characteristics that are full of the interests of countries that next door; involvement of development actors of related countries: inter-state government, inter-local government, inter-community government; formulating a common vision of development, accommodating the needs of two countries and mutually beneficial; and the formulation of policies, strategies and development projects through joint management mechanisms that accommodate the needs of two countries and mutually beneficial.

\section{Regulations related to the authority of the Provincial Government}

Article 1 number 28 of Law no. 26 of 2007 on Spatial Planning classifies the borderland into a national strategic area, namely as an area where priority regulation is prioritized because it has a very important influence nationally on state sovereignty, defense and state security, economy, social, culture and environment. The authority of the Provincial Government shall be stipulated in Article 10, whereas the Authority of the District/Municipal Government is provided for in Article 11 of Law No. 26 of 2007. Provincial and District/Municipal Governments in the implementation of spatial arrangements include the arrangement, guidance and supervision on the implementation of spatial layout of provinces, and districts/municipalities, as well as on the implementation of spatial planning of provincial and district/municipal strategic areas. In the spatial planning of the strategic areas of provinces and districts/municipalities, namely borderlands, including structuring, spatial planning, utilization, and control. In the provisions of Article 10 paragraph (4) of Law no. 26 Of 2007, the implementation of spatial use and control of spatial utilization of provincial strategic areas can be implemented by district/municipal government through the establishment task, and in the provisions of Article 11 paragraph (6) of Law no. 26 of 2007 stated that if the local government of district / municipality can not comply the minimum service standard of spatial planning, the provincial government can take the settlement step in accordance with the provisions of the legislation.

Borderland as regulated in Article 1 point 6 of Law no. 43 of 2008 is part of the territory of the State which lies on the inside side of the border of Indonesia with other countries, in the case of borderland of the country on land, the borderland is in the subdistrict. The authority of the Provincial and District/Municipal Governments in the management of state territories and borderlands shall be regulated in Article 11 and Article 12 of Law no. 43 of 2008. Article 11 of Law no. 43 of 2008 states that the Provincial Government is authorized to implement the Government's policies and establish other policies in the context of regional autonomy and

\footnotetext{
${ }^{23}$ Sadjijono, Understanding Some Basic Chapters of Administrative Law, Yogyakarta: LaksBang Pressindo, 2008, p. 86

${ }^{24}$ Robert Simbolon, Dissertation Proposal, Op.cit, p. 56
} 
assistance tasks; coordinate development in Borderlands; undertaking the development of the inter-regional Borderland and/or between local governments and third parties; and supervise the implementation of Borderland Development implemented by District/ Municipal Government. In addition, the Provincial Government is obliged to establish the cost of the Borderland development.

Law no. 43 of 2008 regulates the National Management Agency and Regional Management Board in the management of borderlands of the country and borderlands. Article 15 of Law no. 43 of 208 provides that the Governing Body has the duty to determine the policies of the border development program; stipulate the budget needs plan; coordinate implementation; and carry out evaluation and supervision. The working relationship between the management body is a coordinating relationship, and in carrying out its duties, the governing body is assisted by a permanent secretariat domiciled in the ministry of the interior. Construction of authority and institution in the management of state borders according to Law no. 43 of 2008 is a consequence of applying the principle of decentralization in the system of governance in Indonesia, where the relationship between the central government and local government built in a system of division of authority and government affairs. Thus, in the management of state borders also applied the principle of decentralization, deconcentration and duty of assistance in accordance with the principles adopted by Law no. 23 of 2014 on Local government

Regions or borderlands are also regulated in Law no. 23 of 2014. Article 361 of Law no. 23 of 2014 provides that there is the authority of the central government in the borderlands, including all authority on the management and utilization of borderlands in accordance with the provisions of the laws on the territory of the state. The Governor is a representative of the central government which coordinates the implementation of borderland development based on the guidelines set by the Central Government; The Governor is assisted by the Regent/Mayor; The mayor provides development assistance assistance by assigning subdistrict heads in borderlands; The Central Government is obliged to build borderlands so as not to be left behind by the progress of borderlands in neighboring countries; so that the authority of the Central Government is regulated outside Article 361 of Law no. 23 Of 2014 becomes the authority of the Region. Meanwhile, related to Article 362 of Law no. 23 Of 2014, the establishment of sub-districts in the borderlands is established by district regulation after obtaining approval from the Minister.

The Borderland is certainly vulnerable to disputes with neighboring countries, pushing the National Archives of the Republic of Indonesia as in Arsip Nasional Republik Indonesia (ANRI) and DPR RI in drafting the Law no. 43 Of 2009 on Archives. The maintained archive is a state archive relating to the existence and survival of the nation and state which must be maintained for its integrity, security and safety. The archive program is a safeguard and safeguard procedure that relates to demography, territorial, archipelagic, international agreements, work contracts and strategic governance issues. Types and categories of Records Archive relating to governance in the Borderland as stipulated in the Regulation of the Head of National Archives of the Republic of Indonesia no. 41 Of 2015 on Management of Maintained Archive.

Furthermore, to manage the borderland, the Government has established the National Border Management Agency (BNPP) on January 28, 2010 through Presidential Regulation no. 12 of 2010, as amended to become Presidential Regulation no. 44 of 2017 on the Amendment of Presidential Regulation no. 12 of 2010 on the National Agency for Border Management and followed up by Minister of Home Affairs Regulation no. 31 Of 2010 on Organization and Administration of BNPP. This is a follow-up of Law no. 43 of 2008 which mandates that to manage state borders and manage borderlands at the central and regional levels, national and 
local governments shall establish National Management Bodies and Local governments. However, the execution of programs in the borderland still overlaps between sectors and institutions, and the lack of coordination due to different sectoral ego and priorities.

\section{Disharmonization and Harmonization of Borderland}

In practice, the application of legislation in the administration of government in borderlands, simultaneously can lead to legal disharmony, namely by the overlapping of authority and conflict of interest among stakeholder institutions. Harmonization and synchronization of legislation as a regulation in the administration of governance in the borderlands is very necessary, or in other words governance is required so as not to collide between one legislation with other laws and regulations. Here are the factors that the occurrence of legal disharmony: 25

1. The number of laws and regulations that apply so much in the management of coastal areas.

2. The existence of customary law increasingly marginalized in the management of coastal areas.

3. Pluralism in the application and law enforcement in the field of coastal area management.

4. Differences of interests and differences in interpretation of the stakeholders of natural resources coastal areas.

5. Gaps between technical understanding and legal understanding of coastal management.

6. Legal obstacles encountered in the application of legislation, consisting of regulatory mechanisms, administrative arrangements, anticipated changes, and law enforcement.

7. Legal obstacles encountered in the application of legislation, namely in the form of overlapping authority and conflict of interest.

8. Implementation of legislation can lead to four possible impacts on stakeholders: diffused cost-diffused benefits, diffused cost-concentrated benefits, concentrated costdiffused benefits, and concentrated cost-concentrated benefits.

The fact of the existence of various legal impacts that can be caused by the application of legislation indicates that harmonization is an effort to be done so that the impact of the law as positive as possible, so as not to cause disharmony of law. Harmonization has the function of prevention and function of overcoming the occurrence of legal disharmony done through the discovery of law, legal reasoning, and rational argumentation. Harmonization of the Law can be pursued through the following steps: ${ }^{26}$

1. Identify the position or position of law disharmony in the application of legislation.

2. Identify the cause of law disharmony.

3. The effort of legal findings by using the method of interpretation and method of legal construction to change the legal state of disharmony into harmony.

4. Efforts of legal findings so that the results of interpretation and construction of the law makes sense or comply the element of logic.

5. Preparation of a rational argument by using an understanding of integrated coastal management techniques to support and explain the results of legal interpretation, legal construction, and legal reasoning.

\footnotetext{
25 Tommy H. Purwaka, "Facts for Harmonization", pp. 559, cited by BPHN, Department of Law and Human Rights, Legal Development Planning on Legal Harmonization of Marine Resource Management in the Decentralization Framework, Jakarta: BAPPENAS, 2005, p. 92

26 Kemitraan Partnership, Op.cit, p. 14
} 
Harmonization of legislation in the framework of borderland management has also formulated some basic principles proposed to be used as a reference for the drafting of local regulations. The use of basic principles as a reference for the drafting of local regulations is expected to prevent the occurrence of legal disharmony and vice versa is expected to improve the harmonization of law between local regulations, and between regional regulations and legislation at the central level.

The main focus of the harmonization of law on borderlands are:

1. Settlement and establishment of state borders;

2. Improved defense, security and law enforcement efforts;

3. Increased economic growth of borderlands;

4. Improvement of basic social services including education and health;

5. Strengthening of institutional capamunicipal in the development of integrated borderlands;

6. Increasing the construction of supporting facilities and infrastructure for communities in borderlands.

Additionally, there is a further effort in creating harmonization and synchronization of legislation in governance in the archipelago, by empowering maintained archive that aims to maintain the integrity and defend the Unitary State of the Republic of Indonesia. The relationship between the archives and the laws and regulations in governance in the archipelago:

1. Viewed from the affairs of the Mandatory Government that are not related to the Basic Service

2. Programs, types and categories of archives are maintained.

On its implementation that must be supervised, the boundaries of the islands, both coastal boundaries and outer boundaries, overlap between government affairs, as regulated in Law no. 23 of 2014, and the provisions of laws and regulations that have not been clearly regulated regarding the assignment of duties and authority to the government concerned. Instead, in the implementation of governance in the archipelago not only run the Law no. 23 of 2014 on Local government, but also must pay attention to other laws and regulations as a gate of Indonesia. In addition, in implementing legal harmonization, legal discovery, legal reasoning, and rational argumentation are required. In addition, the complexity of border issues should be handled in an integrated manner between the local government and the central and relevant agencies under the control of a single command.

To achieve the objectives of effective borderland management, there needs to be cross coordination, sector and government agencies under the auspices of a ministry in implementing the program in the borderland so as to have an echo and a felt impact for the people in the region. The following efforts should be undertaken: ${ }^{27}$

1. Strengthening the social, economic and cultural fields.

2. Increased access to government services and public services and security in general in borderlands.

3. Interconnection and operability across government institutions so that the existing government programs will quickly feel the impact and benefits.

4. Strengthening human resource capamunicipal at the border.

5. Preparation of boundary and land border management patterns.

6. Preparation of maritime boundary management pattern.

27 Op.cit, p. 21 
7. Environmental monitoring and optimization of natural resources to ensure sustainable regional economic growth.

\section{CONCLUSION}

The state of society around the borderland of the country and the handling of the problem of the boundaries of the state become the dominant central government alone. This fact shows many policies that are not mutually supportive and/or less synchronized with each other. Management of borderlands and outer islands involving many agencies, both related agencies at the central level and between central agencies with local governments running in their respective interests. With regard to the authority of the central government in the management of the borders has been only on the border gates. However, the limited authority so that local governments can not play a maximum role in the management of the region. Another factor is the inadequate capamunicipal in the management of borderlands. If the borderland is not immediately managed properly and effectively, certainly the sovereignty of the state will soon be at stake. In addition, the application of legislation in the administration of government in borderlands, simultaneously can lead to legal disharmony, namely by the overlapping of authority and conflict of interest among stakeholder institutions.

Nevertheless, in connection with the results of research on border management in Indonesia, there are suggestions as follows:

1. Agree with the proposal of the Regional Representatives Council (DPD) that it is necessary to have a separate ministry on the border as a state organ authorized in the management of borderlands in Indonesia.

2. Should apply other countries in terms of managing the border, especially the islands, such as the Philippines, Inggris, China and Malaysia by building infrastructure in the outer islands, building military bases and placing communities to inhabit and manage small outer islands.

\section{Reference \\ Books}

Akhmad Musyafak, 2015, Mapping Agroecosystem and Socio-Economic for Border of Bengkayang-Serawak Agricultural Development West Kalimantan, Yogyakarta: Deepublish

Djenal Hosen Koesoemahatmadja, Principles of State Administrative Law, Bandung: Alumni, 1983, hlm. 40

E. Utrecht, 1960, Introduction to Indonesian State Administration Law, Fourth ed., Jakarta: Ikhtiar

Ishak, Awang Faroek, 2003, Development of border areas of Kalimantan in order to maintain and maintain national integrity, Jakarta: Indomedia, Jakarta: Indomedia

Nandang Alamsah Deliarnoor, 2017, Governmental Law, Bandung: UNPAD Press , et.al., 2017, Theory \& Practice of Authority, Yogyakarta: Pandiva Press

Ridwan H.R., 2013, State Administrative Law, Jakarta: Raja Grafindo Persada

Sadjijono, 2008, Understanding Some Basic Chapters of Administrative Law, Yogyakarta: LaksBang Pressindo Riyadi, et.al., 2015, Indikator Kesejahteraan Rakyat 2015 Welfare Indicators 2015, Jakarta: Badan Pusat Statistik

Sutaryo, et.al., 2015, Building the Sovereignty of Nations Based on Pancasila Values: Community Empowerment in the Outermost, Left, and Underdeveloped Area (3T). Yogyakarta: Tim Pusat Pancasila UGM

Zulkifli, 2012, International Cooperation as a Solution for the Management of the State Border Area (Case Study of Indonesia), Jakarta

\section{Regulations}

Law No. 26 of 2007 on Spatial Planning; 
Law No. 27 of 2007 on Management of Coastal Area and Small Islands;

Law No. 43 of 2008 on State Territories;

Law No. 1 of 2014 on Amendment of Law No. 27 Of 2007 on Management of Coastal Area and Small Islands;

Law No. 23 of 2014 on Local government;

Government Regulation No. 26 of 2008 on National Spatial Plan;

Government Regulation No. 62 of 2010 concerning Utilization of the Smaller Outermost Islands;

Government Regulation No. 11 of 2017 concerning Spatial Plan of State Borderland;

Presidential Regulation No. 11 of 2017 on Spatial Planning of State Borderland in North Sulawesi Province, Gorontalo Province, Central Sulawesi Province, East Kalimantan Province and North Kalimantan Province; and

Presidential Regulation No. 44 of 2017 on the Amendment of Presidential Regulation no. 12 of 2010 on the National Border Management Agency.

Regulation of the Head of Archive No. 41 of 2015 on Management of Maintained Archive

\section{Other Sources}

Attachment to Regulation of the Head of BNPP No. 2 of 2015 Date: 13 April 2015 Tentan Strategic Plan National Border Management Agency 2015-2019

Hasim As'ari, Dissertation: Implementation of Policy Management of Small Islands Outlying in Riau Islands Province, Bandung: Unpad, 2017, p. 280

Imam Edy Mulyono, Dissertation Proposal: Analysis of Coordination Patterns of Government Institutions in Border Management and Small Island Outlying (Study on Miangas Island of Talaud Regency of North Sulawesi Province), Bandung: Unpad, 2017, p. 6-7

Indepth the study of borderland issues can be accessed on the website http://kawasan.bappenas.go.id, downloaded on 12 January 2017

Kompas, Article: https://www.pressreader.com/indonesia/kompas/20170911/281938838074234, downloaded Kompas, 11 Sep 2017

Nandang Alamsah Deliarnoor, "Management of Boderland in Context of Comtemporary Government", presented at National Seminar, (presented at Islam University Riau, Pekanbaru, 24 November 2017)

Partnership Partnership, Policy Paper No. 2/2011: Indonesia Border Area Management Policy, May 2011, p. 3-4, can be accessed on the website www.kemitraan.or.id

Regional Development Planning Board of Riau Islands Province, Exposure Presentation: Case Study of Border Area Management in Riau Islands Province, p. 14

Robert Simbolon, Dissertation Proposal: State Border Governance In Indonesia: Studies of Institutional Border Management Country, Bandung: Unpad, 2017, p. 84

Tommy H. Purwaka, "Facts for Harmonization", pp. 559, cited by BPHN, Department of Law and Human Rights, Legal Development Planning on Legal Harmonization of Marine Resource Management in the Decentralization Framework, Jakarta: BAPPENAS, 2005, p. 92 